\title{
Delayed maximum northern European summer temperatures during the Last Interglacial as a result of Greenland Ice Sheet melt
}

\author{
R.T. Jones ${ }^{1 *}$, C.S.M. Turney ${ }^{2}$, B. Lang ${ }^{3}$, S.J. Brooks ${ }^{4}$, M. Rundgren ${ }^{5}$, D. Hammarlund ${ }^{5}$, S. Björck ${ }^{5}$, and C.J. Fogwill ${ }^{2}$ \\ ${ }^{1}$ Geography, College of Life and Environmental Sciences, Exeter University, Devon EX4 4RJ, UK \\ ${ }^{2}$ Climate Change Research Centre, School of Biological, Earth and Environmental Sciences, University of New South Wales, Sydney \\ NSW 2052, Australia \\ ${ }^{3} 12$ Chapel Walks, Kirkham, Preston, Lancashire PR4 2TA, UK \\ ${ }^{4}$ Life Sciences, Natural History Museum, London SW7 5BD, UK \\ ${ }^{5}$ Quaternary Sciences, Department of Geology, Lund University, SE-223 62 Lund, Sweden
}

\begin{abstract}
Here we report a new quantitative mean July temperature reconstruction using non-biting midges (chironomids) from the Danish Last Interglacial (LIG) site Hollerup (spanning 127-116 ka). We find that peak mean July temperatures of $17.5^{\circ} \mathrm{C}$, similar to those of the present day (1961-1990 CE), were reached shortly before the onset of the regional Carpinus pollen zone. Through comparison to terrestrial and marine sequences we demonstrate that peak summer warmth took place some three millennia after the onset of LIG warming in Europe, a marked delay in line with records from the North Atlantic. Crucially, the warmest northern European summer temperatures appear to follow maximum Greenland Ice Sheet mass loss, implying that meltwater substantially reduced Atlantic Meridional Overturning Circulation and depressed European temperatures during the early part of the interglacial.
\end{abstract}

\section{INTRODUCTION}

Changing rates of deep-water formation, sea-ice extent, and ice-sheet stability in the North Atlantic region are considered potential tipping elements in the Earth system with long-term (multi-centennial) global impacts (Lenton et al., 2008; Thomas, 2016). While post-1975 CE Atlantic Meridional Overturning Circulation (AMOC) appears to be markedly slowing down as a result of Greenland Ice Sheet melt (Rahmstorf et al., 2015), it remains uncertain whether the system is approaching a critical threshold (Böning et al., 2016). Natural archives of periods during which global temperatures were warmer than at present potentially provide insights into the stability of the North Atlantic. An excellent example is the Last Interglacial (LIG; Marine Isotope Stage 5e; ca. 127-110 ka) when global mean temperatures were $0-2{ }^{\circ} \mathrm{C}$ warmer than during the pre-industrial period (Otto-Bliesner et al., 2013; Turney and Jones, 2010), similar to the Intergovernmental Panel on Climate Change Representative Concentration Pathway (RCP) 2.6 scenario for the end of the $21^{\text {st }}$ century (IPCC, 2013). Although there were differences in the Earth's orbital configuration, the LIG may provide insights into Earth system processes operating at temperatures above those of the present day.

Analysis of ice-core and marine LIG temperature trends suggests that early warming occurred across the mid- to high latitudes of the Southern Hemisphere (Capron et al., 2014; Turney and Jones, 2010) with a delayed peak in northern sea-surface temperatures (SSTs) and Greenland ice melt relative to the global ice volume minimum (Hillaire-Marcel et al., 2001; NEEM Community Members, 2013). In contrast, climate model studies and terrestrial pollen and chironomid studies imply that the North Atlantic thermal maximum was attained near the onset of the LIG (Brewer et al.,

*E-mail: r.t.jones@ex.ac.uk
2008; Otto-Bliesner et al., 2013) with variable interglacial temperatures at high northern latitudes (Helmens et al., 2015), suggesting a considerably more complex climate trajectory than in the Southern Hemisphere.

Here we report a chironomid-based July temperature reconstruction from the mid-latitude LIG site of Hollerup (Denmark). We compare the new quantified temperature reconstruction to published records, providing new insights into the evolution of summer temperatures across the North Atlantic.

\section{STUDY SITE AND METHODS}

The LIG site of Hollerup in Jutland, Denmark ( $\left.56^{\circ} 24^{\prime} 23^{\prime \prime} \mathrm{N}, 9^{\circ} 50^{\prime} 46^{\prime \prime} \mathrm{E}\right)$ (Fig. 1), preserves a 4.8-m-thick sequence of lacustrine and fluvial sediments sandwiched between glaciogenic sediments (Björck et al., 2000; Rundgren et al., 2005). The sequence includes three distinct lacustrine units (L2 to L4) (Fig. 2) overlying a lower Saalian till (L1) (equivalent to Marine Isotope Stage 6) and capped by Weichselian sand of fluvial origin (L5). A total of 99 contiguous samples were recovered from the sequence, spanning 3-12 cm vertical intervals through units L2 to L5 (4.78-0 m). From these, chironomid analysis was undertaken on 77 samples from lacustrine units L2 to L4 (4.78-0.37 m; approximately every $4-5 \mathrm{~cm}$ depending on sediment availability) following Lang et al. (2003). A minimum of 50 chironomid larval head capsules per sample was targeted to ensure a statistically reliable data set (Larocque, 2001). Chironomid head capsules were identified following Brooks et al. (2007).

Of the 77 sediment samples processed for chironomids, 44 yielded larval head capsules, within which 66 taxa were identified to genus or species morphotype. Where the head capsule numbers were low, adjacent samples were combined to generate $>50$ heads per sample, resulting in 26 data points. No head capsules were recovered below $4.63 \mathrm{~m}$ or above 0.47 $\mathrm{m}$. Calibration of the chironomid assemblage to mean July air temperature (MJT) was undertaken using a modern 274-lake Norwegian-Swiss data set (Heiri et al., 2011). Temperature reconstructions were made using a

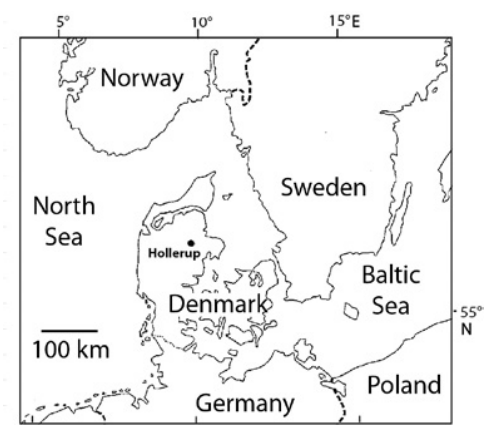

Figure 1. Location of Hollerup, Gudenå Valley, northern Denmark. 


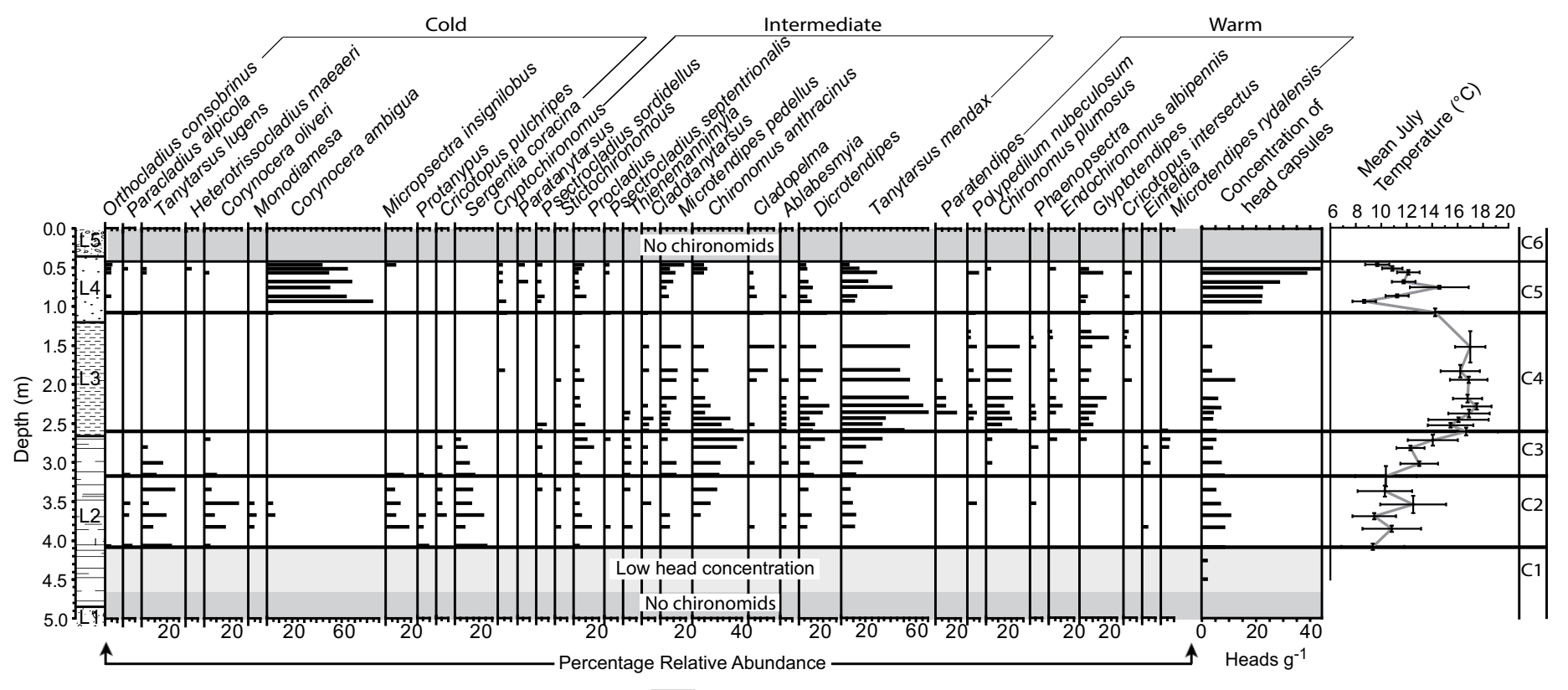

O.g Minerogenic unit $\quad \square$ Laminated calcareous gyttja

Figure 2. Percentage abundance of chironomid taxa and concentration of larval head capsules (per gram of dry sediment) from Hollerup (Denmark). Diagram shows major taxa $>5 \%$ relative abundance, arranged from left to right by thermal preference (July air temperature optimum), subdivided into five assemblage zones (C1-C5) and compared to lithostratigraphic units (L1-L5). Error bars on mean July temperature represent weighted standard deviation.

two-component weighted averaging-partial least squares regression (WAPLS) inference model having a root mean squared error of prediction of $1.33^{\circ} \mathrm{C}$, a coefficient of determination $\left(\mathrm{r}^{2}{ }_{\text {jack }}\right.$ [jack-jack-knifed]) of 0.88 , and a maximum bias ${ }_{\text {jack }}$ of $0.80{ }^{\circ} \mathrm{C}$, all estimated by leave-one-out crossvalidation. When the inference model is constrained to mean July air temperature as the sole explanatory variable, the ratio of the eigenvalues of canonical correspondence analysis axis 1 against unconstrained axis 2 is 1.17 , indicating that mean July air temperature is a strong predictor of chironomid assemblage composition (Juggins, 2013). Sample-specific errors of the inferred temperatures were estimated by 999 bootstrap cycles. The robustness of the MJT reconstruction was also assessed (Telford and Birks, 2011) (see the GSA Data Repository ${ }^{1}$ ).

A chronological framework for the Hollerup sequence was originally developed by Björck et al. (2000), who cross-correlated the pollen stratigraphy with the annually laminated record from Bispingen, Germany, $\sim 440 \mathrm{~km}$ to the southeast (Müller, 1974). While debate surrounds the duration of the LIG (Brauer et al., 2007), vegetation development across northern Europe appears to be broadly synchronous on sub-millennial time scales (e.g., Grüger, 1991), allowing the identification of regional pollen zones that provide a first-order chronology (see Table DR1 in the Data Repository). As a result, we place the onset of the LIG at ca. $127 \mathrm{ka}$ following Brauer et al. (2007). Our chronological framework is not meant to provide an absolute chronology; rather our focus here is on the relative timing of peak July warmth to regional palyno-stratigraphy.

\section{THE CHIRONOMID RECORD}

The chironomid record was subdivided into five assemblage zones (C1 to C5) identified using constrained incremental sum of squares clustering (Fig. 2). Head capsules in zone C1 (4.63-4.07 m) were exclusively from cold-stenothermic taxa (Sergentia coracina, Micropsectra insignilobus, and Tanytarsus lugens), but the number of head capsules recovered was too low to be statistically reliable. Statistically reliable

${ }^{1}$ GSA Data Repository item 2017006, chironomid temperature calibration details and northern European pollen scheme, is available online at www.geosociety .org/pubs/ft2017.htm or on request from editing @ geosociety.org. counts were produced in zone C2 (4.07-3.17 m), and cold-stenothermic taxa again dominated the record. In zone $3(3.17-2.60 \mathrm{~m})$ there is a pronounced shift toward intermediate taxa, particularly Chironomus anthracinus and T. mendax, coincident with declining frequencies of $S$. coracina and T. lugens. The zone C4 (2.60-1.08 $\mathrm{m})$ assemblage is dominated by intermediate (T. mendax and $C$. anthracinus) and warm-water taxa $(C$. plumosus and Glyptotendipes). The uppermost zone C5 (1.08-0.47 m) preserves the reemergence of what are characterized as cold-water taxa in the modern training set, especially Corynocera ambigua (Bedford et al., 2004; Larocque-Tobler et al., 2010; Luoto et al., 2008), while a few warm-water taxa are also present, many of which are reported for this period in European LIG records (Brodersen and Bennike, 2003; Helmens et al., 2015). For a discussion of significance testing and potential bias issues, see the Data Repository.

Reconstructed MJT spans from the early part of regional pollen zone (RPZ)-IV (Corylus phase) to the end of RPZ-VII (Pinus phase) (Fig. 3). Across the record, MJT varies by $\sim 10{ }^{\circ} \mathrm{C}$ around a mean of $13{ }^{\circ} \mathrm{C}$. In the later part of RPZ-IV, MJT increases by $\sim 7^{\circ} \mathrm{C}$, peaking at $\sim 17.5^{\circ} \mathrm{C}$ between 2.6 and $2.3 \mathrm{~m}$ (ca. $124 \mathrm{ka}$ ) across the transition to RPZ-V (Carpinus phase). The rise in MJT occurs at a time of high biological productivity, reflected by the precipitation of thick autochthonous marl deposits (Fig. 3). The maximum in MJT is coincident with the first of two lake-level low stands; event $\mathrm{A}$ is the less severe of the two low stands with no significant lithological change. Overall, MJT at Hollerup remains high and stable throughout RPZ-V, averaging $\sim 16.5^{\circ} \mathrm{C}$. The decrease in carbon:nitrogen $(\mathrm{C}: \mathrm{N})$ and increasing total organic carbon throughout RPZ-V and the early part of RPZ-VI indicate stabilization of catchment soils and increasing productivity in the lake system.

During the later stages of the interglacial (ca. 119-117 ka), MJT declines but fluctuates markedly (Fig. 3). Temperatures appear to have reached a minimum of $8^{\circ} \mathrm{C}$ within RPZ-VI (ca. $118 \mathrm{ka}$ ) before increasing to $\sim 14.1{ }^{\circ} \mathrm{C}$, after which there is a gradual decline to $9{ }^{\circ} \mathrm{C}$. No chironomid head capsules were recovered from the interval $1.31-1.15 \mathrm{~m}$, coincident with the second more severe phase of lake-level lowering (event B; Fig. 3 ), during which subaerial exposure or bottom freezing would explain the absence of head capsules (Björck et al., 2000). 
Importantly, warmest reconstructed MJT at Hollerup was $\sim 17.5^{\circ} \mathrm{C}$, similar to the 1961-1990 CE climate mean for northern Denmark and $1{ }^{\circ} \mathrm{C}$ below the upper temperature range sampled by the Norwegian-Swiss training set (Heiri et al., 2011). Because of the tendency of WA-PLS models to underestimate temperatures toward the upper end of the range covered by the model, it is possible that the reconstructed $17.5^{\circ} \mathrm{C}$ may be below peak temperatures, although we consider that this is unlikely to exceed the sample-specific error estimates presented. Regardless, this peak in MJT across the onset of the Carpinus phase is in marked contrast to pollen-derived temperatures that suggest that the Corylus phase (RPZ-IV) represents the LIG "climatic optimum" (Brewer et al., 2008; Cheddadi et al., 1998). While chironomid larvae develop during summer, winter temperatures are considered a major control on the distribution of Corylus, and its rapid expansion during the LIG a reflection of milder winters (Cheddadi et al., 1998). We therefore consider that the Hollerup record provides evidence for peak July temperatures and reduced seasonality in Denmark approximately three millennia after the onset of the LIG.

\section{WIDER IMPLICATIONS}

The delayed rise in summer temperature has potentially important implications for understanding climate forcing and sea-level change during the LIG. Crucially, peak MJT temperatures occur at the end of RPZ-IV and at the onset of the Carpinus phase (Fig. 4), allowing us to place the temperature trends within the northern European palyno-stratigraphy and investigate LIG climate mechanisms. The timing of rising summer temperatures at ca. 126-124 ka appears to parallel SSTs in the North Atlantic (e.g., core MD95-2042, Iberian margin; Shackleton et al., 2003) and leads the trend in northern Europe (e.g., Sokli, northern Finland; Helmens et al., 2015) (Fig. 4). The establishment of peak interglacial warmth occurs after peak summer insolation but coincident with vegetation establishment around the Greenland coast, implying a reduction in ice-sheet melt (Hillaire-Marcel et al., 2001) (Fig. 4). We do not observe the subsequent summer Tunturi cooling event (ca. $120 \mathrm{ka}$ ) recorded at Sokli and in other high-latitude marine sequences (Fig. 4), though the relatively low density of sampling levels through the upper part of Hollerup precludes us from completely discounting this possibility. The origin of this event remains unclear, but it appears to be restricted to high latitudes, suggesting a different mechanism to the proposed reduction in AMOC.

Recent work on core MD03-2664 (northeast Labrador Sea) has identified substantially reduced North Atlantic Deep Water and increased Greenland-sourced ice rafting during the onset of the LIG (Galaasen et al., 2014) subsequent to Antarctic ice sheet melt (Fogwill et al., 2011, 2014; Hayes et al., 2014). The implication is that Greenland Ice Sheet melt (possibly with contributions from final Laurentide and Saalian decay) sufficiently weakened the AMOC to offset heat and moisture transfer from the North Atlantic over Europe (Bakker et al., 2014). Of the 6.6-9.4 m above present global sea level during the LIG (Kopp et al., 2009), the Greenland Ice Sheet is estimated to have contributed between $5.1 \mathrm{~m}$ (Yau et al., 2016) and $0.7 \mathrm{~m}$ (Quiquet et al., 2013). With the observed weakening of AMOC since $1975 \mathrm{CE}$ as a consequence of Greenland Ice Sheet melt (Rahmstorf et al., 2015), our results are consistent with a high North Atlantic sensitivity to a relatively small freshwater input.

\section{CONCLUSIONS}

The reconstructed MJT for the LIG at Hollerup indicates that summer temperatures were similar to those of the 1961-1990 CE period. A three-millennia delay in peak summer temperatures is observed relative to northern European development of temperate forest and consistent with North Atlantic SST reconstructions. Crucially, we find that the warmest northern European summer temperatures follow maximum Greenland Ice Sheet melt. Our results imply that enhanced Greenland Ice Sheet melt may have substantially reduced AMOC and temperatures across the North Atlantic during the early part of the LIG. Future work is urgently needed to

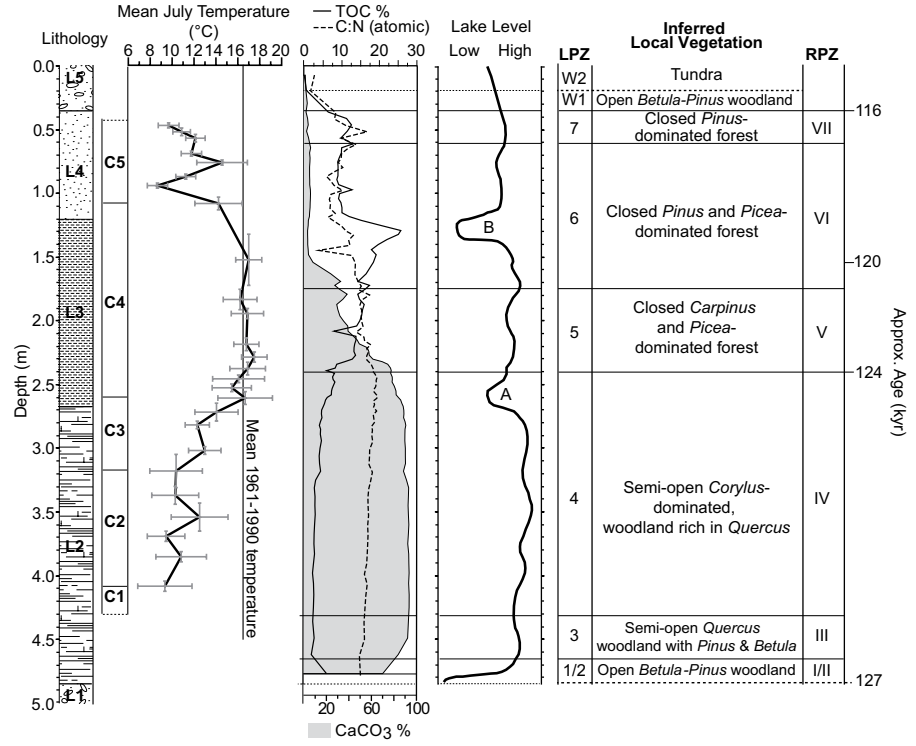

Figure 3. Chironomid-inferred mean July temperature for Hollerup (Denmark) compared against key lithological (percent total organic carbon [TOC], carbon:nitrogen [C:N], percent $\mathrm{CaCO}_{3}$ ) and lake-level data. Local pollen zone (LPZ) scheme and inferred local vegetation are plotted in relation to regional pollen zone (RPZ) scheme for northern Europe (Grüger, 1991; Müller, 1974) (Table DR1 [see footnote 1]). L1-L5-lithologic units (see Fig. 2); C1-C5-chironomid assemblage zones (see Fig. 2).
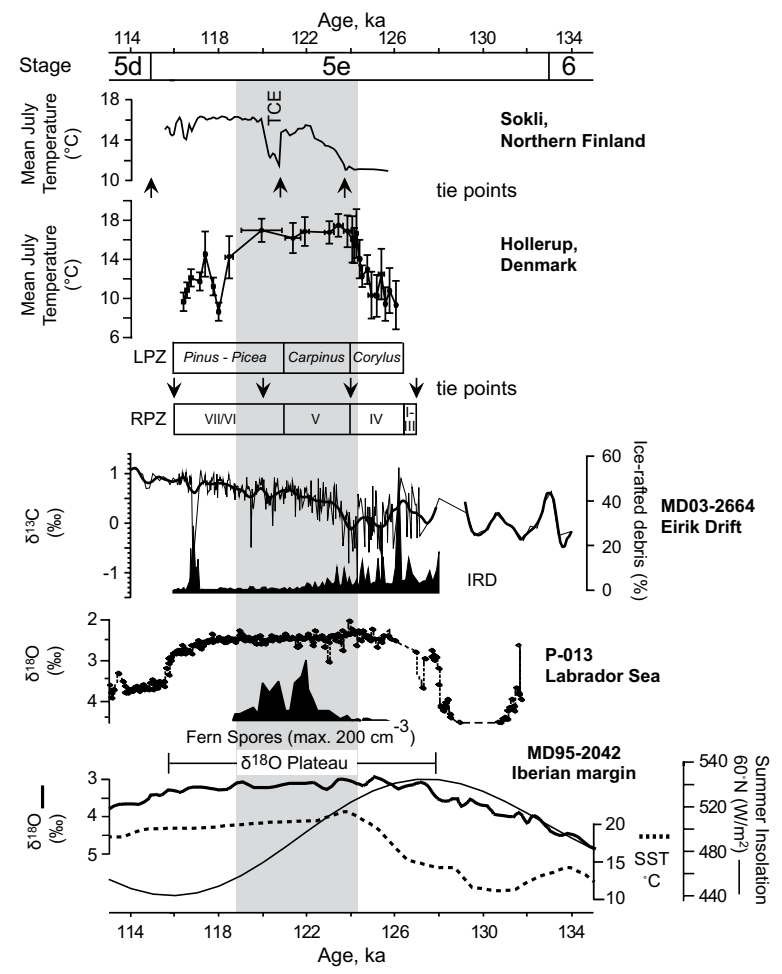

Figure 4. Hollerup (Denmark) chironomid-inferred mean July temperature (MJT) compared against Sokli (northern Finland) pollen MJT reconstruction showing Tunturi cooling event (TCE) (Helmens et al., 2015), Labrador Sea $\delta^{13} \mathrm{C}$ and ice-rafted debris from core MD03-2644 (Galaasen et al., 2014) and $\delta^{18} O$ and fern spore records from core P-013 (Hillaire-Marcel et al., 2001), and $\delta^{18} O$ and sea-surface temperature (SST) records from Iberian margin core MD95-2042 (Shackleton et al., 2003). Summer insolation at $60^{\circ} \mathrm{N}$ is derived from Berger (1978). Gray column denotes period of sustained maximum Hollerup temperatures. Stage-Marine Isotope Stage; LPZ—local pollen zone; RPZ—regional pollen zone. 
more precisely constrain the relative contributions of ice sheets to LIG sea levels to better understand AMOC sensitivity to projected future warming.

\section{ACKNOWLEDGMENTS}

Turney and Fogwill thank the Australian Research Council (grants FL100100195, FT120100004, LP120200724). Thanks to Bjørn Buchardt for providing the C:N data, Angela Self for help with statistical analysis, David Campbell and Alan Bedford for laboratory work, and three reviewers for their constructive comments.

\section{REFERENCES CITED}

Bakker, P., Renssen, H., and Van Meerbeeck, C.J., 2014, Early Last Interglacial Greenland Ice Sheet melting and a sustained period of meridional overturning weakening: A model analysis of the uncertainties: Climate Dynamics, v. 43, p. 1025-1039, doi:10.1007/s00382-013-1935-1.

Bedford, A., Jones, R.T., Lang, B., Brooks, S., and Marshall, J.D., 2004, A Lateglacial chironomid record from Hawes Water, northwest England: Journal of Quaternary Science, v. 19, p. 281-290, doi:10.1002/jqs.836.

Berger, A., 1978, Long-term variations of caloric insolation resulting from the Earth's orbital elements: Quaternary Research, v. 9, p. 139-167, doi:10.1016 /0033-5894(78)90064-9.

Björck, S., Noe-Nygaard, N., Wolin, J., Houmark-Nielsen, M., Hansen, H.J., and Snowball, I., 2000, Eemian Lake development, hydrology and climate: A multi-stratigraphic study of the Hollerup site in Denmark: Quaternary Science Reviews, v. 19, p. 509-536, doi:10.1016/S0277-3791(99)00025-6.

Brauer, A., Allen, J.R., Mingram, J., Dulski, P., Wulf, S., and Huntley, B., 2007, Evidence for last interglacial chronology and environmental change from Southern Europe: Proceedings of the National Academy of Sciences of the United States of America, v. 104, p. 450-455, doi:10.1073/pnas.0603321104.

Brewer, S., Guiot, J., Sánchez-Goñi, M., and Klotz, S., 2008, The climate in Europe during the Eemian: A multi-method approach using pollen data: Quaternary Science Reviews, v. 27, p. 2303-2315, doi:10.1016/j.quascirev.2008.08.029.

Brodersen, K.P., and Bennike, O., 2003, Interglacial Chironomidae (Diptera) from Thule, Northwest Greenland: Matching modern analogues to fossil assemblages: Boreas, v. 32, p. 560-565, doi:10.1111/j.1502-3885.2003.tb01235.x.

Brooks, S.J., Langdon, P.G., and Heiri, O., 2007, The identification and use of Palaearctic Chironomidae larvae in palaeoecology: Quaternary Research Association Technical Guide 10, $276 \mathrm{p}$.

Capron, E., Govin, A., Stone, E.J., Masson-Delmotte, V., Mulitza, S., Otto-Bliesner, B., Rasmussen, T.L., Sime, L.C., Waelbroeck, C., and Wolff, E.W., 2014, Temporal and spatial structure of multi-millennial temperature changes at high latitudes during the Last Interglacial: Quaternary Science Reviews, v. 103, p. 116-133, doi:10.1016/j.quascirev.2014.08.018.

Cheddadi, R., Mamakowa, K., Guiot, J., De Beaulieu, J.-L., Reille, M., Andrieu, V., Granoszewski, W., and Peyron, O., 1998, Was the climate of the Eemian stable? A quantitative climate reconstruction from seven European pollen records: Palaeogeography, Palaeoclimatology, Palaeoecology, v. 143, p. 73-85, doi:10.1016/S0031-0182(98)00067-4.

Fogwill, C.J., Hein, A.S., Bentley, M.J., and Sugden, D.E., 2011, Do blue-ice moraines in the Heritage Range show the West Antarctic ice sheet survived the last interglacial?: Palaeogeography, Palaeoclimatology, Palaeoecology, v. 335-336, p. 61-70, doi:10.1016/j.palaeo.2011.01.027.

Fogwill, C.J., Turney, C.S.M., Meissner, K.J., Golledge, N.R., Spence, P., Roberts, J.L., England, M.H., Jones, R.T., and Carter, L., 2014, Testing the sensitivity of the East Antarctic Ice Sheet to Southern Ocean dynamics: Past changes and future implications: Journal of Quaternary Science, v. 29, p. 91-98, doi: $10.1002 / j q s .2683$.

Galaasen, E.V., Ninnemann, U.S., Irvalı, N., Kleiven, H.F., Rosenthal, Y., Kissel, C., and Hodell, D.A., 2014, Rapid reductions in North Atlantic Deep Water during the peak of the last interglacial period: Science, v. 343, p. 1129-1132, doi:10.1126/science. 1248667 .

Grüger, E., 1991, Late Quaternary biostratigraphy in northern Germany 150 000-15 000 years B.P.: Striae, v. 34, p. 7-14.

Hayes, C.T., Martínez-García, A., Hasenfratz, A.P., Jaccard, S.L., Hodell, D.A., Sigman, D.M., Haug, G.H., and Anderson, R.F., 2014, A stagnation event in the deep South Atlantic during the last interglacial period: Science, v. 346, p. 1514-1517, doi:10.1126/science.1256620.

Heiri, O., Brooks, S.J., Birks, H.J.B., and Lotter, A.F., 2011, A 274-lake calibration data-set and inference model for chironomid-based summer air temperature reconstruction in Europe: Quaternary Science Reviews, v. 30, p. 3445-3456, doi:10.1016/j.quascirev.2011.09.006.

Helmens, K.F., Salonen, J.S., Plikk, A., Engels, S., Väliranta, M., Kylander, M., Brendryen, J., and Renssen, H., 2015, Major cooling intersecting peak Eemian Interglacial warmth in northern Europe: Quaternary Science Reviews, v. 122, p. 293-299, doi:10.1016/j.quascirev.2015.05.018.

Hillaire-Marcel, C., De Vernal, A., Bilodeau, G., and Weaver, A., 2001, Absence of deep-water formation in the Labrador Sea during the last interglacial period: Nature, v. 410, p. 1073-1077, doi:10.1038/35074059.
IPCC (Intergovernmental Panel on Climate Change), 2013, Climate Change 2013: The Physical Science Basis-Contribution of Working Group I to the Fifth Assessment Report of the Intergovernmental Panel on Climate Change: Cambridge, UK, Cambridge University Press, 1535 p.

Juggins, S., 2013, Quantitative reconstructions in palaeolimnology: New paradigm or sick science?: Quaternary Science Reviews, v. 64, p. 20-32, doi:10.1016 /j.quascirev.2012.12.014.

Kopp, R.E., Simons, F.J., Mitrovica, J.X., Maloof, A.C., and Oppenheimer, M., 2009, Probabilistic assessment of sea level during the last interglacial stage: Nature, v. 462, p. 863-867, doi:10.1038/nature08686.

Lang, B., Bedford, A., Richardson, N., and Brooks, S., 2003, The use of ultrasound in the preparation of carbonate and clay sediments for chironomid analysis: Journal of Paleolimnology, v. 30, p. 451-460, doi:10.1023/B:JOPL .0000007307 .09971 .19 .

Larocque, I., 2001, How many chironomid head capsules are enough? A statistical approach to determine sample size for palaeoclimatic reconstructions: Palaeogeography, Palaeoclimatology, Palaeoecology, v. 172, p. 133-142, doi: 10.1016/S0031-0182(01)00278-4.

Larocque-Tobler, I., Heiri, O., and Wehrli, M., 2010, Late Glacial and Holocene temperature changes at Egelsee, Switzerland, reconstructed using subfossil chironomids: Journal of Paleolimnology, v. 43, p. 649-666, doi:10.1007 /s10933-009-9358-z.

Lenton, T.M., Held, H., Kriegler, E., Hall, J.W., Lucht, W., Rahmstorf, S., and Schellnhuber, H.J., 2008, Tipping elements in the Earth's climate system: Proceedings of the National Academy of Sciences of the United States of America, v. 105, p. 1786-1793, doi:10.1073/pnas.0705414105.

Luoto, T.P., Nevalainen, L., and Sarmaja-Korjonen, K., 2008, Multiproxy evidence for the 'Little Ice Age' from Lake Hampträsk, Southern Finland: Journal of Paleolimnology, v. 40, p. 1097-1113, doi:10.1007/s10933-008-9216-4.

Müller, H., 1974, Pollenanalytische Untersuchungen und Jahresschichtenzählungen an der eem-zeitlichen Kieselgur von Bispingen/Luhe: Geologisches Jahrb A, v. 21 , p. $149-169$.

NEEM (North Greenland Eemian Ice Drilling) Community Members, 2013, Eemian interglacial reconstructed from a Greenland folded ice core: Nature, v. 493, p. 489-494, doi:10.1038/nature11789.

Otto-Bliesner, B.L., Rosenbloom, N., Stone, E.J., McKay, N.P., Lunt, D.J., Brady, E.C., and Overpeck, J.T., 2013, How warm was the last interglacial? New model-data comparisons: Philosophical Transactions of the Royal Society of London A: Mathematical, Physical and Engineering Sciences, v. 371 , 20130097, doi:10.1098/rsta.2013.0097.

Quiquet, A., Ritz, C., Punge, H., and Salas y Mélia, D., 2013, Greenland ice sheet contribution to sea level rise during the last interglacial period: A modelling study driven and constrained by ice core data: Climate of the Past, v. 9, p. 353-366, doi:10.5194/cp-9-353-2013.

Rahmstorf, S., Box, J.E., Feulner, G., Mann, M.E., Robinson, A., Rutherford, S., and Schaffernicht, E.J., 2015, Exceptional twentieth-century slowdown in Atlantic Ocean overturning circulation: Nature Climate Change, v. 5, p. 475-480, doi:10.1038/nclimate2554.

Rundgren, M., Björck, S., and Hammarlund, D., 2005, Last interglacial atmospheric $\mathrm{CO}_{2}$ changes from stomatal index data and their relation to climate variations: Global and Planetary Change, v. 49, p. 47-62, doi:10.1016/j.gloplacha .2005.04.002.

Shackleton, N.J., Sánchez-Goñi, M.F., Pailler, D., and Lancelot, Y., 2003, Marine Isotope Substage 5e and the Eemian Interglacial: Global and Planetary Change, v. 36, p. 151-155, doi:10.1016/S0921-8181(02)00181-9.

Telford, R., and Birks, H., 2011, A novel method for assessing the statistical significance of quantitative reconstructions inferred from biotic assemblages: Quaternary Science Reviews, v. 30, p. 1272-1278, doi:10.1016/j.quascirev .2011.03.002

Thomas, Z.A., 2016, Using natural archives to detect climate and environmental tipping points in the Earth system: Quaternary Science Reviews, v. 152, p. 60-71, doi:10.1016/j.quascirev.2016.09.026.

Turney, C.S., and Jones, R.T., 2010, Does the Agulhas Current amplify global temperatures during super-interglacials?: Journal of Quaternary Science, v. 25, p. 839-843, doi:10.1002/jqs.1423.

Yau, A.M., Bender, M.L., Robinson, A., and Brook, E.J., 2016, Reconstructing the last interglacial at Summit, Greenland: Insights from GISP2: Proceedings of the National Academy of Sciences of the United States of America, v. 113, p. 9710-9715, doi:10.1073/pnas.1524766113.

Manuscript received 25 July 2016

Revised manuscript received 6 October 2016

Manuscript accepted 8 October 2016

Printed in USA 